\title{
イオン窒化およびイオン軟窒化処理した 鉄鋼の化合物層の比較
}

$\begin{array}{llll}\text { 枝村 瑞郎** } & \text { 牧村 } & \text { 実** } & \text { 梶川亭 志** } \\ \text { 今井孝 —** } & \text { 古都 } & \text { 敏** } & \text { 国瀬 悟** }\end{array}$

Mizuo Edamura, Minoru Makimura, Takashi Kajikawa, Kōichi Imai, Satoshi Furuitsu and Satoru Kunise : The Comparison of the Compound Layers in Ion-nitrided and Ion-softnitrided Steels. The volume ratio of $\varepsilon-\mathrm{Fe}_{2-3} \mathrm{~N}$ phase to the sum of $\varepsilon-$ $\mathrm{Fe}_{2-3} \mathrm{~N}$ and $\gamma^{t}-\mathrm{Fe}_{4} \mathrm{~N}$ phases in the compound layers in ion-nitrided and ion-softnitrided $\mathrm{S} 15 \mathrm{C}, \mathrm{S} 48 \mathrm{C}, \mathrm{SCM} 3$, and SACM 1 steels were measured using the X-ray diffraction pattern. The microstructures of $\varepsilon-\mathrm{Fe}_{2-3} \mathrm{~N}, \gamma^{\prime}-\mathrm{Fe}_{4} \mathrm{~N}$ and $\mathrm{Fe}_{3} \mathrm{C}$ phases were observed by transmission electron microscopy and electron diffraction. The main results were as follows.

(1) The ratio of $c_{\varepsilon} /\left(c_{s}+c_{\gamma^{\prime}}\right)$ for ion-nitrided SACM 1 steel was relatively large (about $0.4 \sim$ 0.7 ), but those for ion-nitrided SCM $3, S 48 \mathrm{C}$, and $\mathrm{S} 15 \mathrm{C}$ steels were less than $0.4,0.25$, and 0.15 respectively. Here $c_{8}$ and $c_{r^{\prime}}$ were the volume fractions of $\varepsilon-\mathrm{Fe}_{2-3} \mathrm{~N}$ phase and $r^{\prime}-\mathrm{Fe}_{4} \mathrm{~N}$ phase in the compound layer.

(2) The ratio of $c_{s} /\left(c_{s}+c_{r^{\prime}}\right)$ for ion-softnitrided steels were larger than those for ionnitrided steels.

(3) When the nitriding temperature raised, the ratio of $c_{\varepsilon} /\left(c_{t}+c_{r^{\prime}}\right)$ was increased.

(4) The hardness of the surface in ion-nitrided and ion-soft-nitrided steels generally increased with increase in the value of $c_{\varepsilon} /\left(c_{s}+c_{\tau^{\prime}}\right)$.

(5) The shape and amount of $\varepsilon-\mathrm{Fe}_{2-3} \mathrm{~N}, \gamma^{\prime}-\mathrm{Fe}_{4} \mathrm{~N}$ and $\mathrm{Fe}_{3} \mathrm{C}$ phases in the compound layers were observed by transmission electron microscopy. Each phase was detected by the electron diffraction pattern.

(Received January 30, 1978)

\section{I. 緒 言}

著者らは先に(1)イオン軟窒化に和ける幾つかの処理因子 (雾囲気ガス組成，全がス圧，グロ一電流密度，グロー電 玨)が窒化層の生成に及ぼす影響について，イオン窒化の 場合と比較しつつ検討した。 その結果，窒化層のうち特に

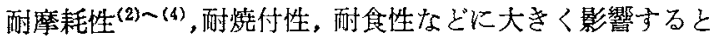
考兄ら机る最表面部の化合物層の組成については，ガス組 成に大さく依存することが見出された。しかしながら，ガ 又組成と化合物層の組成の関係の把握は半定量的なむので あり，また従来の文献にる兩者の関俰が定量的に記述され ていることはほとんどない，そこで，本研究ではすず雨者 の関係を定量的炕握するため，化合物層に生成される 窒化鉄 (稠密六万晶の $\varepsilon-\mathrm{Fe}_{2-3} \mathrm{~N}$ 特よび面心立方晶の $\left.\gamma^{\prime}-\mathrm{Fe}_{4} \mathrm{~N}\right)$ のちち $\varepsilon-\mathrm{Fe}_{2-3} \mathrm{~N}$ の占める割合を $\mathrm{X}$ 線回折図形よ
り求め，ガス組成との関係を検討した，さらに，窒化温度 が化合物層の組成に影響を及ぼすことも考兄られるので， その点についても検討した。また，それらの結果之化合物 層の硬さや電子顕微鏡による組織観察との比較検討を行な った。

\section{II. 試料および実験方法}

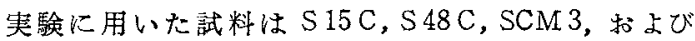
SACM 1 であり, Table 1 にそれらの化学成分と前処理 を示した。試料の形状は直径 $15 \mathrm{~mm}$, 高さ $50 \mathrm{~mm}$ の円柱 状である。

妈理装置は前報(1) と同じすを使用した。陰極支持台に 試料をせットし，陽極との間に全波整流された直流電圧を 印加した，陽極材には溶融フルミニウムめっき鋼板を黑化 処理(5)したものを用いた，全ガス圧はピラニーおよびマク

Table 1 Chemical composition(wt\%) and heat treatment of specimens.

\begin{tabular}{|c|c|c|c|c|c|c|c|c|c|}
\hline Specimen & $\mathrm{C}$ & $\mathrm{Si}$ & $\mathrm{Mn}$ & $P$ & S & $\mathrm{Cr}$ & Mo & $\mathrm{A} 1$ & Heat treatment \\
\hline $\begin{array}{l}\text { S } 15 \mathrm{C} \\
\text { S } 48 \mathrm{C} \\
\text { SCM } 3 \\
\text { SACM1 }\end{array}$ & $\begin{array}{l}0.15 \\
0.48 \\
0.35 \\
0.42\end{array}$ & $\begin{array}{l}0.26 \\
0.28 \\
0.20 \\
0.27\end{array}$ & $\begin{array}{l}0.52 \\
0.88 \\
0.74 \\
0.45\end{array}$ & $\begin{array}{l}0.010 \\
0.012 \\
0.012 \\
0.013\end{array}$ & $\begin{array}{l}0.018 \\
0.023 \\
0.019 \\
0.007\end{array}$ & $\begin{array}{l}\overline{-} \\
0.99 \\
1.49\end{array}$ & $\begin{array}{l}\overline{-} \\
0 . \overline{15} \\
0.18\end{array}$ & $\frac{-}{1.20}$ & $\begin{array}{l}930^{\circ} \mathrm{C} \mathrm{A.C.} \\
860^{\circ} \mathrm{C} \text { A. C } \\
850^{\circ} \mathrm{C} \text { O. Q., } 600^{\circ} \mathrm{C} \mathrm{O} \text {. Q. } \\
920^{\circ} \mathrm{C} \text { O. Q., } 700^{\circ} \mathrm{C} \mathrm{O.} \mathrm{Q.}\end{array}$ \\
\hline
\end{tabular}

** 川崎重工業株式会社発動機事業本部(Engine and Motorcycle Group, Kawasaki Heavy Industries Ltd., Akashi)

*イオン軟窒化の研究(第 2 報) 
ラウド真空計で測定したが，両者で指示值が異る場合は後 者の值を採用した。流量は湿式流量計で検定された浮子式 面積流量計で測定し，各ガスを同一のガス管に集合させた 後，真空反応炉内に供給した、温度測定にはインコネルで 被覆した CA 熱電対を用いた。

イオン軟窒化処理の 1 サイクルは前報(1) と同様である。 昇温和よび窒化処理中において，イオン衝撃時に発生する 熱に上る加熱以外に発熱体汇上る加熱的併用した。この方 法を用いることにより，処理条件の如何にかかわらずグロ 一電流密度を一定に保つことなと゚ができ，試料の温度分布 も均一保持することができる。なお，全がス压，グロー 電流密度, 窒化時間はそれぞれ $400 \mathrm{~Pa}$ (3 torr)，11.5 $\mathrm{A} / \mathrm{m}^{2}, 6 \mathrm{~h}$ と一定にし，窒化処理後はただちに炉を開き， 試料を別設請けた冷却槽にて水冷した。水冷時の試料表面 の泠却速度は $700^{\circ} \mathrm{C} / \mathrm{s}$ である。

\section{III. 実験結果および考察}

\section{1. 化合物層に生成される空化鉄のうち $\varepsilon-\mathrm{Fe}_{2-3} \mathrm{~N}$ の 占める割合}

試料最表面の化合物磨に生成される窒化鉄 $\left(\varepsilon-\mathrm{Fe}_{2-3} \mathrm{~N}\right.$ 市 よび $\left.\gamma^{\prime}-\mathrm{Fe}_{4} \mathrm{~N}\right)$ のちち $\varepsilon-\mathrm{Fe}_{2-3} \mathrm{~N}$ の占める割合を以下に示 す方法でX線回折図形より求めた。

ディフラクトメータでの単一相試料の回折線の単位長さ 当たりの積分強度 $I$ は式 (1)で与元られる(6).

$$
I=\left(I_{0} e^{4} / m^{2} c_{0}^{4}\right)\left(\lambda^{3} A / 32 \pi r\right)\left(1 / v^{2}\right)
$$

$\left[|F|^{2} p\left(1+\cos ^{2} 2 \theta\right) / \sin ^{2} \theta \cdot \cos \theta\right]\left(e^{-2 \mathrm{M} / 2} \mu\right)(1)$

ただし， $I_{0}$ : 入射ビームの強度， $e$ : 電子の電荷, $m$ : 電子の質量, $c_{0}$ : 光速, $\lambda:$ 入射光線の波長, $r:$ ディフラ クトメータ円の半径, $A$ : 入射ビームの断面積, $v:$ 単位 格子の体積, $F$ : 構造因子, $p:$ 多重度因子, $\theta:$ ブラッグ 角, $e^{-2 \mathrm{M}}$ : 温度因子, $\mu$ : 線吸收係数である。

ところで窒化処理により化合物層に生成される物質( $\mathrm{Fe}_{2-3} \mathrm{~N}, \gamma^{\prime}-\mathrm{Fe}_{4} \mathrm{~N}, \mathrm{Fe}_{3} \mathrm{C}, \mathrm{Fe}_{3} \mathrm{O}_{4}$ など)は攺とえど $\mathrm{Fe}$ 原子
で母格子が形成されており，それらの質量吸收係数(7)に大 きな差はないと考えられる。そこで, $\varepsilon-\mathrm{Fe}_{2-3} \mathrm{~N}$ と $\gamma^{\prime}-\mathrm{Fe}_{4} \mathrm{~N}$ について，それぞれの特定の回折線のみに着目すれば，式 (1)は次のように拡張される(6).

$$
\begin{aligned}
& \left.\begin{array}{l}
I_{\mathrm{s}}=K R_{\mathrm{z}} c_{\mathrm{z}} / 2 \mu_{m} \\
I_{\tau^{\prime}}=K R_{r^{\prime}} c_{r^{\prime}} / 2 \mu_{m}
\end{array}\right\} \\
& \text { ここで, } K:\left(I_{0} e^{4} / m^{2} c_{0}^{4}\right)\left(\lambda^{3} A / 32 \pi r\right) \\
& R:\left(1 / v^{2}\right)\left[|F|^{2} p\left(1+\cos ^{2} 2 \theta\right) /\right. \\
& \left.\sin ^{2} \theta \cdot \cos \theta\right](e-2 \mathrm{M}) \\
& \mu_{m}: \text { 混合組織の線吸収保数 } \\
& c_{s}, c_{\boldsymbol{r}^{\prime}}: \text { 各相の体積率 }
\end{aligned}
$$

である、ところで，Kは回折物質の種類や量高無関保な定 数なので, 着目した回折ピークの積分強度を三角形近似法 で求め， $R_{\varepsilon}, R_{\tau^{\prime}}$ を算出すれば，式(2)から試料最表面の 化合物層に生成される窒化鉄 $\left(\varepsilon-\mathrm{Fe}_{2-3} \mathrm{~N}\right.$ 呿よび $\left.\gamma^{\prime}-\mathrm{Fe}_{4} \mathrm{~N}\right)$ のうち $\varepsilon-\mathrm{Fe}_{2-3} \mathrm{~N}$ の占める割合 $c_{s} /\left(c_{8}+c_{\gamma^{\prime}}\right)$ を求めること ができる。

\section{2. 霝团気ガス組成と化合物層の $c_{s} /\left(c_{\boldsymbol{t}}+c_{\boldsymbol{r}^{\prime}}\right)$}

Fig.1 は窒化温度を $550^{\circ} \mathrm{C}$ と一定にしたとき添加 $\mathrm{C}_{3} \mathrm{H}_{8}$ がなし，0.5\%および $1 \%$ の各場合について， $\mathrm{N}_{2}$ ガス濃 度が化合物層の $c_{\mathrm{a}} /\left(c_{\mathrm{a}}+c_{r^{\prime}}\right)$ にどの上らな影響があるかを

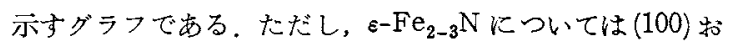
上び(101)面に関して別個に求めた平均值を， $\gamma^{\prime}-\mathrm{Fe}_{4} \mathrm{~N}$ に ついては (200)面に関して求めた值を用いた。な怙，vを 得るにあたり，格子定数を $\varepsilon-\mathrm{Fe}_{2-3} \mathrm{~N}$ は $a=2.745, c=$ $4.415, \gamma^{\prime}-\mathrm{Fe}_{4} \mathrm{~N}$ は $a=3.79$ とした。

さて四によれば， $\mathrm{C}_{3} \mathrm{H}_{8}$ なしの通常のイオン窒化の場合， $c_{\mathrm{s}} /\left(c_{\mathrm{z}}+c_{\gamma^{\prime}}\right)$ の值は $\mathrm{N}_{2}$ ガス濃度が增加するにつれて徐々 に增加するものの, S $15 \mathrm{C} て ゙ は 0.15$ 以下, S $48 \mathrm{C} て ゙ は$ 0.25 以下, SCM 3 で 0.4 以下と此較的低い值であり, $\varepsilon-\mathrm{Fe}_{2-3} \mathrm{~N}$ よりも $\gamma^{\prime}-\mathrm{Fe}_{4} \mathrm{~N}$ の方が生成されやすいことがわ かる。ただし, SACM1については $c_{a} /\left(c_{\mathrm{t}}+c_{r^{\prime}}\right)$ の值は

\section{$550^{\circ} \mathrm{C} \times 6 \mathrm{~h} \rightarrow$ W.Q. $\quad 400 \mathrm{~Pa}(3 \mathrm{torr})$}

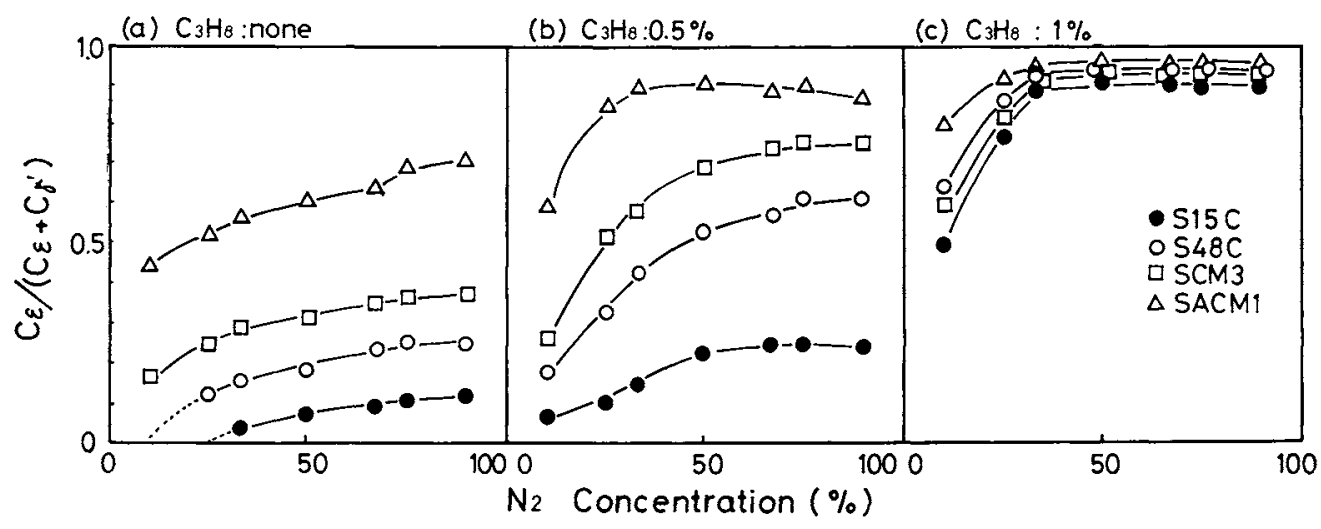

Fig.1 Effect of gas composition upon the volume ratio of $\varepsilon-\mathrm{Fe}_{2-3} \mathrm{~N}$ phase to the sum of $\varepsilon-\mathrm{Fe}_{2-3} \mathrm{~N}$ and $\gamma^{\prime}-\mathrm{Fe}_{4} \mathrm{~N}$ phases in the compound layer. 
$0.4 \sim 0.7$ と比較的高く, $\mathrm{C}_{3} \mathrm{H}_{8}$ を添加しなくて子 $\varepsilon-\mathrm{Fe}_{2-3} \mathrm{~N}$ はかなり生成されることを示している。な特，S15Cでは $\mathrm{N}_{2}$ ガス濃度が $25 \%$ 以下，S48Cでは $\mathrm{N}_{2}$ ガス濃度が $10 \%$ 以下和いて， $c_{\varepsilon} /\left(c_{\mathrm{s}}+c_{\gamma}\right)$ の值は零，すなわち $\gamma^{\prime}-\mathrm{Fe}_{4} \mathrm{~N}$ 単相の化合物層となる。一方， $\mathrm{C}_{3} \mathrm{H}_{8}$ を0.5\%添加したイ オン軟窒化の場合は， $\mathrm{C}_{3} \mathrm{H}_{8}$ を添加しない場合より。 $c_{8}$

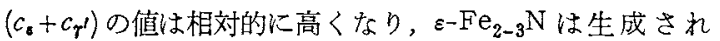
やすくなる，さらに $\mathrm{C}_{3} \mathrm{H}_{8}$ を $1 \%$ 添加すると，各試料とる $\mathrm{N}_{2}$ ガス濃度が $33 \%$ 以上では， $c_{\varepsilon} /\left(c_{\varepsilon}+c_{\tau^{\prime}}\right)$ の値が 0.9 以上 となり， $\gamma^{\prime}-\mathrm{Fe}_{4} \mathrm{~N}$ はほとんど生成されなくなる。ただし， $\mathrm{C}_{3} \mathrm{H}_{8}$ を $1 \%$ 添加した場合 $\mathrm{Fe}_{3} \mathrm{C}$ もわずか火生成され， $\varepsilon-\mathrm{Fe}_{2-3} \mathrm{~N}$ も Cをかなり固溶していると考光られる。この よらに $\mathrm{N}_{2}-\mathrm{H}_{2}-\mathrm{C}_{3} \mathrm{H}_{8}$ のがス

組成を変觉ることにより， 化合物層の組成が大きく変 化することがかかる、な和， 各試料とあX線回折で同定 された窒化物は窒化鉄のみ であった。

\section{3. 窒化温度と化合物厢 Ф $c_{s} /\left(c_{s}+c_{r^{\prime}}\right)$}

Fig.2はガス組成を $\mathrm{N}_{2}$ : $\mathrm{H}_{2}=2: 1$ (添加 $\mathrm{C}_{3} \mathrm{H}_{8}: 1 \%$ ) すなわら, $\mathrm{N}_{2}, \mathrm{H}_{2}, \mathrm{C}_{3} \mathrm{H}_{8}$ ガ スの体積濃度をそれぞれ $66 \%, 33 \%, 1 \%$ と同一に して, 窒化温度を変えるこ とにより，化合物層の $c_{\mathrm{a}} /$ $\left(c_{*}+c_{r}\right)$ にどのような影響 があるかを示している.\$15

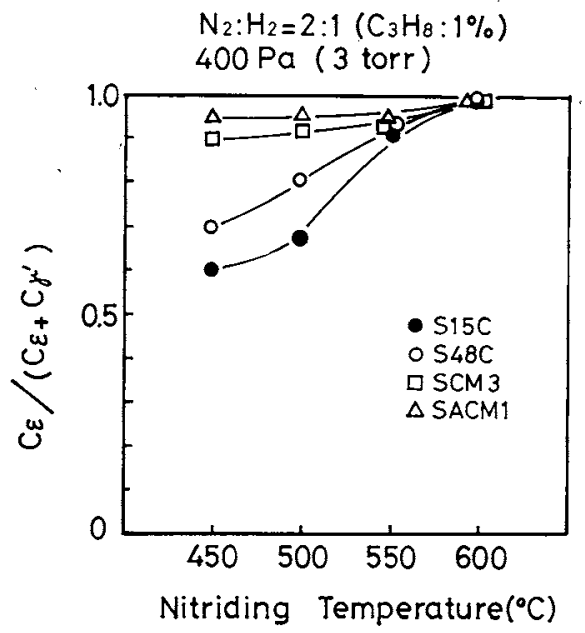

Fig.2 Effect of nitriding temperature upon the volume ratio of $\varepsilon-\mathrm{Fe}_{2-3} \mathrm{~N}$ phase to the sum of $\varepsilon-\mathrm{Fe}_{2-3} \mathrm{~N}$ and $\gamma^{\prime}-\mathrm{Fe}_{4} \mathrm{~N}$ phases in the compound layer (Nitriding time : $6 \mathrm{~h}$ ).
C 拈よび S $48 \mathrm{C}$ の炭素鋼は窒化温度が高くなるにつれて， $c_{\varepsilon} /\left(c_{s}+c_{\gamma^{\prime}}\right)$ の值は増加する。この理由は Fe-N-C 3元系 状態図 ${ }^{(8)}$ に拀いて上記の咥化温度域では，温度が高くなる につれて $\varepsilon-\mathrm{Fe}_{2-3} \mathrm{~N}$ の固溶限が広がるため, $\varepsilon-\mathrm{Fe}_{2-3} \mathrm{~N}$ が生 成されやすくなるためと考えられる。また SCM 3 和よび

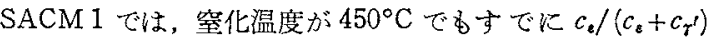
の値は 0.9 以上であり，空化温度により大きな差は生じな い.なお，窒化盜度が $600^{\circ} \mathrm{C}$ では各試料とも $c_{t} /\left(c_{s}+c_{\gamma^{\prime}}\right)$ の值は汪ば 1 であり， $\gamma^{t}-\mathrm{Fe}_{4} \mathrm{~N}$ はほとんど生成されない。

4. 化合物層の硬さと $c_{\mathfrak{s}} /\left(c_{\mathrm{s}}+\boldsymbol{c}_{\mathrm{r}^{\prime}}\right)$

Fig.3 は窒化温度を $550^{\circ} \mathrm{C}$ と一定にして，ガス組成を

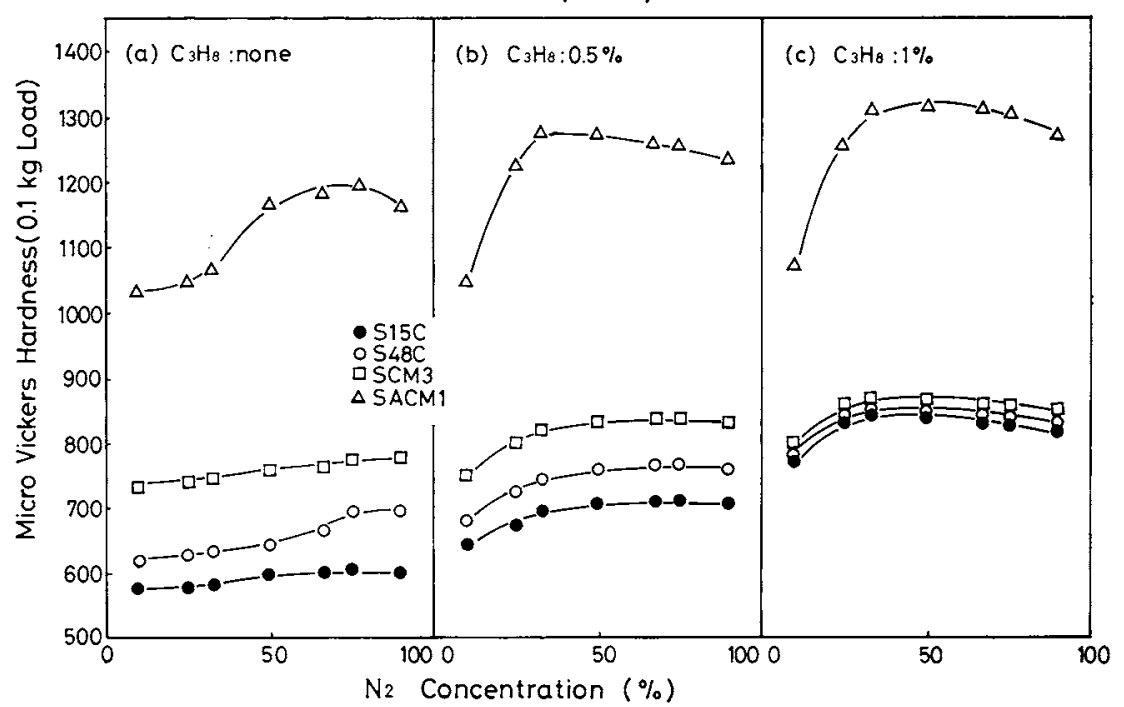

Fig.3 Effect of gas composition upon the hardness of the surface.

変えたときの表面硬さを示寸グラフである。徽小ビッカー 不硬度計(荷重 $0.1 \mathrm{~kg}$ ) の圧痕の深さは約 $2.5 \mu \mathrm{m}$ である

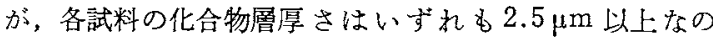
で，本研究では表面硬さを化合物層の硬さと記することに 寸る，図は，ガス組成と化合物層に生成される窒化鉄 $(\varepsilon-$ $\mathrm{Fe}_{2-3} \mathrm{~N}$ おび $\left.\gamma^{\prime}-\mathrm{Fe}_{4} \mathrm{~N}\right)$ のち $\varepsilon-\mathrm{Fe}_{2-3} \mathrm{~N}$ の占める割合 $c_{\varepsilon} /\left(c_{s}+c_{\gamma^{\prime}}\right)$ との関係を示才 Fig.1と，類似の傾向を示し ている。すなわち， $\mathrm{N}_{2}$ ガス濃度を增加，あるいは $\mathrm{C}_{3} \mathrm{H}_{8}$ を 添加していくことによって，化合物層の硬さは増加する が， $c_{8} /\left(c_{8}+c_{\gamma^{\prime}}\right)$ の值も同梯に增加している，特に， $\mathrm{C}_{3} \mathrm{H}_{8}$ を $1 \%$ 添加した場合， $\mathrm{N}_{2}$ ガス濃度が $33 \%$ 以上では，化合 物層の硬さは各試料とも本奏験のなかでは最も高い値を示 しているが， $c_{\varepsilon} /\left(c_{2}+c_{\gamma^{\prime}}\right)$ の値も0.9以上という高い值を示 している。これは化合物層の硬さが主に $c_{\varepsilon} /\left(c_{8}+c_{r}\right)$ により 決定され，比較的硬い $\varepsilon-\mathrm{Fe}_{2-3} \mathrm{~N}$ の量が堌減するに応じて， 化合物層の硬さも增減するためであると考允られる。たた L， $c_{\varepsilon} /\left(c_{\varepsilon}+c_{\gamma^{\prime}}\right)$ の値が同程度でも，他の試料に比べて SACM 1 の化合物層の硬さは高い値を示している。これは 
$\mathrm{A} 1$ など $\mathrm{N}$ との親和力の強 い元素の周固に選択的に $\mathrm{N}$ が集合することによる格子 ひずみ执よび微細な窒化物 の存在によるすべり干涉の ため(9) と考光られる。

また，Fig.4はガス組成 $\mathrm{N}_{2}: \mathrm{H}_{2}=2: 1$ (添加 $\mathrm{C}_{3} \mathrm{H}_{8}$ : $1 \%$ と同一にして, 窒化温 度を変えたときの化合物層 の硬さを示すグラフであ る。窒化温度が $550^{\circ} \mathrm{C}$ 以 下に和应化合物層の硬さ は，S15C 括よび S $48 \mathrm{C}$ の炭素鋼では窒化温度が高 くなるにつれて增加して招

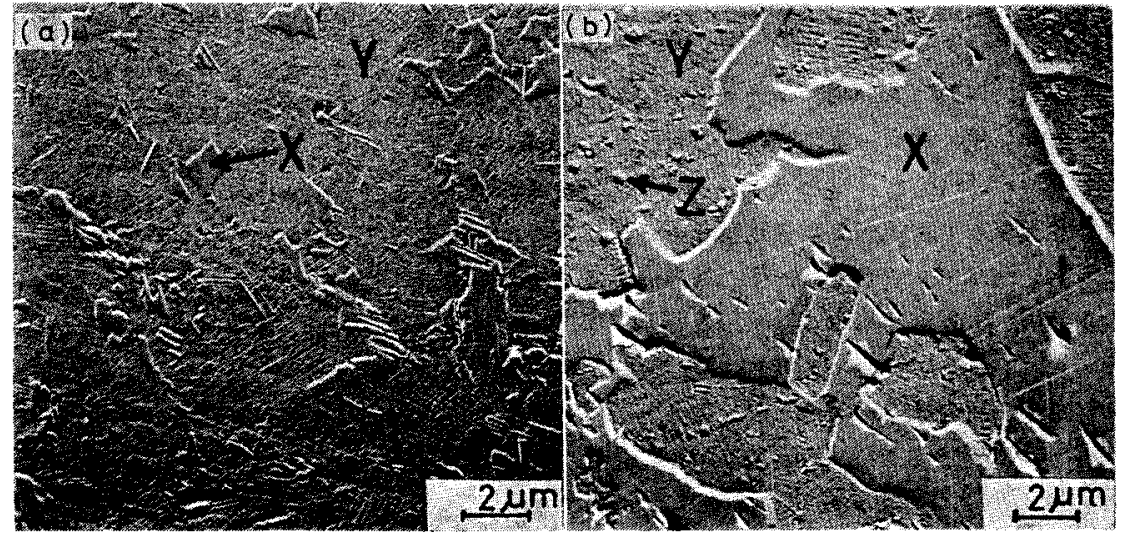

Photo.1 Electron micrographs of the the compound layers.

(a) $\mathrm{S} 15 \mathrm{C} \quad \mathrm{N}_{2}: \mathrm{H}_{2}=1: 2\left(\mathrm{C}_{3} \mathrm{H}_{8}\right.$ : none) $550^{\circ} \mathrm{C} \times 6 \mathrm{~h} \rightarrow \mathrm{W} . \mathrm{Q} . \quad 400 \mathrm{~Pa}(3$ tor $\mathrm{r})$

(b) $\mathrm{S} 48 \mathrm{C} \quad \mathrm{N}_{2}: \mathrm{H}_{2}=2: 1\left(\mathrm{C}_{3} \mathrm{H}_{8}: 1 \%\right)$ $550^{\circ} \mathrm{C} \times 6 \mathrm{~h} \rightarrow \mathrm{W} . \mathrm{Q} . \quad 400 \mathrm{~Pa}(3 \mathrm{torr})$
ク，SCM 3 および SACM 1 では大きな差はない。これは 窒化温度と $c_{\mathrm{a}} /\left(c_{\mathrm{s}}+c_{\mathrm{T}^{\prime}}\right)$ の関係を示す Fig.2 と類似の傾向 にあり，化合物層の硬さは $c_{s} /\left(c_{e}^{2}+c_{r}\right)$ とよい対応関保に

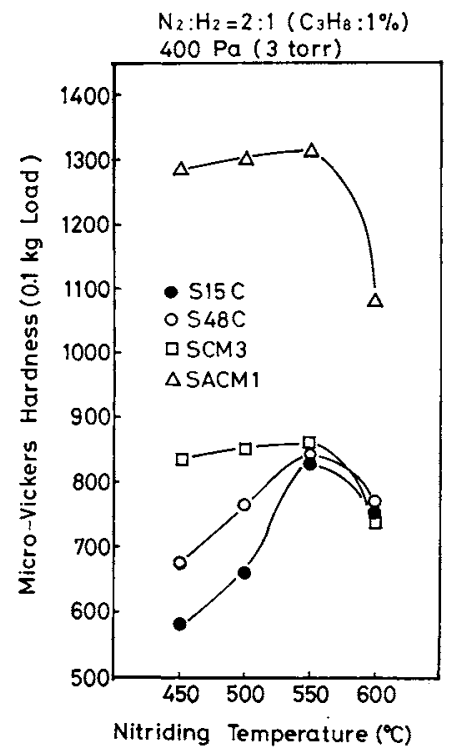

Fig.4 Effect of nitriding temperature upon the hardness of the surface (Nitriding time: $6 \mathrm{~h}$ ).
ある。一方，窣化温度が $600^{\circ} \mathrm{C}$ では各試料とも $c_{z} /\left(c_{t}+c_{\gamma^{\prime}}\right)$ の值は活济 1 と高いにもかかわらず，化合物層の硬さは低 下して扣り，その傾向は特に SCM 3 抢上びSACM 1 亿拉 いて影著にみられる。これは窒化温度が高いことによる窒 化物の粗大化拉よび䅂子ひずみの解消 ${ }^{(10)}$ とるるためと推 定さ礼る。

\section{5. 電子顕微鏡による化合物層の組織観察}

Photo.1 は(a) S 15C $\mathrm{N}_{2}: \mathrm{H}_{2}=1: 2$ (添加 $\mathrm{C}_{3} \mathrm{H}_{8}$ :な し), お上び(b) S $48 \mathrm{C}$ を $\mathrm{N}_{2}: \mathrm{H}_{2}=2: 1$ (添加 $\mathrm{C}_{3} \mathrm{H}_{8}: 1 \%$ )

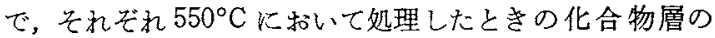
二段レプリカ法による透過電子顕微鏡写真である。腐食液 は硝酸ピクリン酸のメタノール溶液を使用した。写真中， (a) 亿 X，Y，および(b)にX, Y，Zで示した個所と同様の 形態を示す個所を薄膜法でそれぞれ電子線回折 (Photo.2) したところ, X: $:-\mathrm{Fe}_{2-3} \mathrm{~N}, \mathrm{Y}: \gamma^{t}-\mathrm{Fe}_{4} \mathrm{~N}, \mathrm{Z}: \mathrm{Fe}_{3} \mathrm{C}$ であ ることが見出された。これにより，(a)では $\varepsilon-\mathrm{Fe}_{2-3} \mathrm{~N}$ よ りも $\gamma^{\prime}-\mathrm{Fe}_{4} \mathrm{~N}$ の方が極めて多量比成されること，(b)で は逆に $\varepsilon-\mathrm{Fe}_{2-3} \mathrm{~N}$ の方が $\gamma^{\prime}-\mathrm{Fe}_{4} \mathrm{~N}$ 上りる㕣めて多量化生成 され， $\mathrm{Fe}_{3} \mathrm{C}$ すわずか生成されることが確認された。 な 招，化合物買火生成される窒化鉄 $\left(\varepsilon-\mathrm{Fe}_{2-3} \mathrm{~N}\right.$ 打よび $\gamma^{\prime}-$ $\left.\mathrm{Fe}_{4} \mathrm{~N}\right)$ のちち $\varepsilon-\mathrm{Fe}_{2-3} \mathrm{~N}$ の占める割合を示す $c_{s} /\left(c_{s}+c_{\tau^{\prime}}\right)$ の值は，(a)では 0.05 と小さく，(b)では 0.9 と大きく (Fig.1)，上記の傾向とょく一致した。

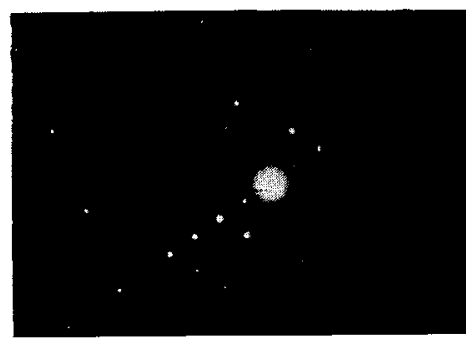

$\mathrm{X}: \boldsymbol{\varepsilon}-\mathrm{Fe}_{2-3} \mathbf{N}$

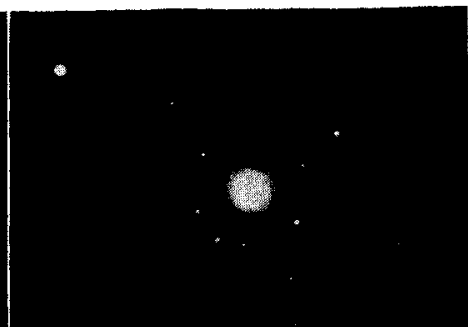

$\mathbf{Y}: \boldsymbol{\gamma}^{\prime}-\mathrm{Fe}_{4} \mathbf{N}$

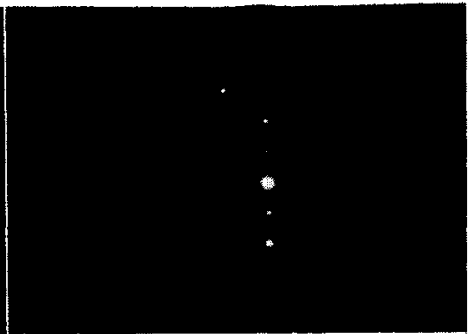

$\mathbf{Z}: \mathbf{F e}_{3} \mathbf{C}$

Photo.2 Electron diffraction patterns of $\varepsilon-\mathrm{Fe}_{2-3} \mathrm{~N}, \gamma^{\prime}-\mathrm{Fe}_{4} \mathrm{~N}$ and $\mathrm{Fe}_{3} \mathrm{C}$ phases. 


\section{IV. 結 論}

$\mathrm{S} 15 \mathrm{C}, \mathrm{S} 48 \mathrm{C}, \mathrm{SCM} 3$ ，和よび SACM 1 の各陚料に対 し，全がス压，グロー電流密度，窒化時間，冷却法をそれ ぞれ $400 \mathrm{~Pa}(3$ torr $), 11.5 \mathrm{~A} / \mathrm{m}^{2}, 6 \mathrm{~h}$, 水冷之同一に乙

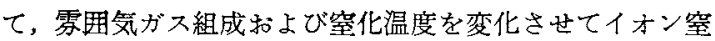
化もしくはイオン軟窒化した後, 試料最表面の化合物層に 生成される窒化鉄 $\left(\varepsilon-\mathrm{Fe}_{2-3} \mathrm{~N}\right.$ 战よび $\left.\gamma^{\prime}-\mathrm{Fe}_{4} \mathrm{~N}\right)$ のちと$\mathrm{Fe}_{2-3} \mathrm{~N}$ の占める割合 $c_{e} /\left(c_{\varepsilon}+c_{\gamma^{\prime}}\right)$ 员線回折図形上り求 めた結果，次の結諭を得た。

(1) $550^{\circ} \mathrm{C}$ でイオン窒化して(添加 $\mathrm{C}_{3} \mathrm{H}_{8}$ ：なし), $\mathrm{Fe}_{2-3} \mathrm{~N}$ が最も生成されやすい錀種は SACM 1 である。次 いで, SCM 3，S48C，S15C の順であるが，これらの $c_{s} /\left(c_{\varepsilon}+c_{\gamma^{\prime}}\right)$ の値はそれ艺れ $0.4,0.25,0.15$ 以下である。

(2) $550^{\circ} \mathrm{C}$ で $\mathrm{C}_{3} \mathrm{H}_{8}$ を添加してイオン敷窒化すると, 1 オン窒化の場合に比して $\varepsilon-\mathrm{Fe}_{2-3} \mathrm{~N}$ は生成されやすくな る。特に， $\mathrm{C}_{3} \mathrm{H}_{8}$ を $1 \%$ 添加すると， $\mathrm{N}_{2}$ ガス濃度が $33 \%$ 以上で各試料とも $c_{\varepsilon} /\left(c_{z}+c_{\gamma^{\prime}}\right)$ の値は 0.9 以上となる.

(3) ガス組成を $\mathrm{N}_{2}: \mathrm{H}_{2}=2: 1$ (添加 $\mathrm{C}_{3} \mathrm{H}_{8}: 1 \%$ ) と同一 にして, 窒化温度を高くすると, $c_{\varepsilon} /\left(c_{\mathrm{e}}+c_{\tau}\right)$ の值は増加す る.

(4) $c_{8} /\left(c_{s}+c_{\tau^{\prime}}\right)$ の值が増減するに応じて，化合物層の硬 さも増减する頵向にある。

(5) $c_{\varepsilon} /\left(c_{8}+c_{\gamma^{\prime}}\right)$ の値が低い試料，打よび高い試料の化
合物辝の組織を電子顕微鏡で観察しだままた，電子線回折 で $\varepsilon-\mathrm{Fe}_{2-3} \mathrm{~N}, \gamma^{\prime}-\mathrm{Fe}_{4} \mathrm{~N}$ ，打よび $\mathrm{Fe}_{3} \mathrm{C} の$ 同定を行ない，電 子顕镜鏡組織観察で認められるそれぞれの空化鉄，炭化鉄 の形態との関連を明確にした。

終りに，本研究に対し御指導と御鞭㨒を貝わった京都大 学工学部 田村今男教授に愿く感謝いたします。また，電子 線回折を実施していたたいた日本電子株式会社に感謝の意 を表します。

\section{文献}

（1）枝村瑞郎，牧村 実, 梶川享志，今井孝一，古都 敏， 国瀬 悟：日本金属学会誌，42(1978)，936.

(2) 兽根 匠, 山中久彦：日本金属学会誌，40(1976), 908 .

（3）兽根 㭽, 山中久彦：日本金属学会誌，41(1977), 620 .

（4）兽根 医, 綱沢采二, 山中久彦：熱処理，17(1977), 151 .

（5）大㭷太郎：東芝レビュ一，24(1969)，789.

(6) カリティ, 松村源太印訳: X線回折要諭, アグネ, (1975), 392 .

(7)辛島誠一: 放射線の金属学への応用, 日本金属学会, (1972), 36.

(8) Metallography Structures and Phase Diagrams, Metals Handbook, vol. 8, ASM, (1973), 411.

（9）日本学術振與会製鋼第 19 委員会緗：鉄鋼亡合金元 素(上)，誠文堂新光社，(1966)，618。

(10) 干早 正, 浦尾完一, 吉阙㹡一期：日本金属学会誌, $39(1975), 156$.

\title{
$\mathrm{Al}-10 \mathrm{wt} \% \mathrm{Zn}$ 合金中の濃度ゆらぎの低温時効への影響*
}

\author{
太田陸奥雄** 山田益男 ${ }^{* *}$ 金谷蛼 人** $^{* *}$ \\ 飛田守孝**螹原精**
}

Mutsuo Ohta, Masuo Yamada, Teruto Kanadani, Moritaka Hida and Akira Sakakibara: Effects of the Fluctuation of Solute Concentration in Al-10wt\% Zn Alloy on Ageing at Lower Temperatures. A1-10 wt $\% \mathrm{Zn}$ alloy was studied by measurements of electrical resistivity and $\mathrm{X}$-ray small-angle scattering intensity and by transmission electron microscopy. Specimens were quenched from mainly $300^{\circ} \mathrm{C}\left(T_{Q 1}\right)$ into lower quenching temperature $\left(T_{Q 2}, 110 \sim 230^{\circ} \mathrm{C}\right)$, maintained for various lengths of time at $T_{Q 2}$, quenched into ice-water and aged isothermally at $0^{\circ}$ or $40^{\circ} \mathrm{C}$. Results obtained are : (1) When the specimen was maintained at $T_{Q 2}$ for a length of sufficient time and aged at relatively high temperature (e.g. $1 \mathrm{~h}$ at $125^{\circ} \mathrm{C}$ and aged at $40^{\circ} \mathrm{C}$ ), a two-step increment of both resistivity and integrated intensity was recognized. (2) Each of the steps has the characteristics of the formation of G.P.zones by the spinodal decomposition. (3) The maximum resistivity $\left(\rho_{\max }\right)$ changes with the maintenance period at $T_{Q 2}$. It decreases at the beginning, then rises gradually through the minimum, and finally attains a constant value. (4) When $\rho_{\max }$ takes a minimum, the width of the size distribution of the G.P. zones estimated from the

** 岡山大学工学部 (School of Engineering, Okayama University, Okayama)

*** 岡山大学大学院, 現在: 岡山理科大学 (Graduate School, Okayama University, Okayama. Present address : Okayama College of Science, Okayama)

* 1973 年 10 月日本金属学会福岡大会, 1977 年 4 月東京大会扰上び同年 10 月広島大会に一部発表 